\begin{tabular}{|l|l|l||}
\hline \multicolumn{2}{|c|}{ PublisherInfo } \\
\hline \hline PublisherName & $:$ & BioMed Central \\
\hline \hline PublisherLocation & $:$ & London \\
\hline \hline PublisherImprintName & $:$ & BioMed Central \\
\hline \hline
\end{tabular}

\title{
Symposium on Recent Novel Therapies in the Treatment of Acute Coronary Syndromes
}

\begin{tabular}{|l|l|l||}
\hline \multicolumn{3}{|c||}{ ArticleInfo } \\
\hline \hline ArticleID & $:$ & 4225 \\
\hline \hline ArticleDOI & $:$ & $10.1186 /$ ccf-1999-webreport10 \\
\hline \hline ArticleCitationID & $:$ & webreport10 \\
\hline \hline ArticleSequenceNumber & $:$ & 13 \\
\hline \hline ArticleCategory & $:$ & Web report \\
\hline \hline ArticleFirstPage & $:$ & 1 \\
\hline \hline ArticleLastPage & $:$ & 3 \\
\hline \hline & & RegistrationDate : 1999-5-21 \\
ArticleHistory & $:$ & OnlineDate \\
\hline \hline ArticleCopyright & $:$ & Current Science Ltd1999-5-21 \\
\hline \hline ArticleGrants & $:$ & \\
\hline \hline ArticleContext & $:$ & 1305433 \\
\hline \hline
\end{tabular}




\section{Overview}

A new symposium has recently been added at the site, entitled 'Recent Novel Therapies in the Treatment of Acute Coronary Syndromes'. Presented as a satellite symposium on Saturday 6 March 1999 at the 1999 American College of Cardiology meeting, this symposium presented new information on the use of ion pumpinhibitors and thrombolytics in the management of cardiovascular disease.

The faculty and topics included:

Robert Roberts, MD, Program Chairman

Metin Avkiran, PhD: Scientific basis of NHE in acute cardiac ischemia

John Speer Schroeder, MD: Clinical potential of NHE inhibition - the GUARDIAN trial

Pierre Theroux, MD, Program Co-Chairman: Panel discussion/Question and answers

Hirudin is superior to heparin in acute coronary syndromes

Point: James H Chesebro, MD

Counterpoint: Robert M Califf, MD

Transcription-only and Multimedia (RealPlayer ${ }^{\circledR}$ technology required) versionsare available both providing the full slide show and the text of the presentations.

\section{Other comments}

March 1999.

\section{Evaluation}

None. 


\section{References}

1. Medical Matrix Symposia on the Web. [http://www.medmatrix.org/symposia]

This PDF file was created after publication. 